\title{
A TREE DECADENCE CLASSIFICATION FOR MATURE CONIFEROUS STANDS
}

\author{
BY R. E. FOSTER, G. P. THOMAS, and J. E. BROWNE'
}

\author{
R. E. FOSTER
}

Born in Vancouver, B.C., 1919. B.A. (Botany and Forestry) 1942 (Brit. Col.), B.S.F. 1943 (Brit. Col.) Ph.D. 1949 (Toronto). Undergraduate forestry experience in bardwood logging operations and with British Columbia Forest Service. Joined the staff of the Division of Forest Biology in 1943 to assist in investigations of decay in British Columbia. Appointed officer in charge of the B.C. Unit of Forest Pathology in 1949.

\section{G.P.THOMAS}

Born in Nortb Vancouver, B.C., 1920. B.A. (Botany and Forestry) 1947 (Brit. Col.), B.S.F. 1948 (Brit. Col.), M.F. 1949 (Yale), residence for Ph.D. $1951-53$ (Brit. Col.). Undergraduate experience in forestry with British Columbia Forest Service. Overseas service with Canadian Army 1942-1946. Joined the staff of Division of Forest Biology in 1947 to undertake investigations of decay in British Columbia. Currently active in studies of the ecology of fungi that cause decay.

\section{E. BROWNE}

Born in Victoria, B.C., 1924. B.S.F. 1949 (Brit. Col.). Undergraduate forestry experience with the Reforestation Division, British Columbia Forest Service and the Division of Forest Biology. Joined the staff of the British Columbia Laboratory of Forest Patbology in 1949 to assist in investigations of decay. Employed with the Surveys Division, British Columbia Forest Service from September, 1952 to carry out studies of decay in relation to the Provincial foret inventory program.

\section{ABSTRACT}

Mature coniferous stands are comprised of trees in varying stages of susceptibility to and deterioration by wood destroying fungi. Individual trees of such stands may be segregated into easily recognized classes by their possession or lack of visible abnormalities indicative of decay. The segregation of trees on the presence or absence of suspect abnormalities may provide reliable information on stand defect.

\section{INTRODUCTION}

Considerable variation in amount of decay may be realized in trees of the same species, size, age and site classification. Such variation may restrict

1 Contribution No. 100, Division of Forest Biology, Seienee Service, Department of Agriculture, Ottawa.

2 Officer-in-Charge, Assistant Forest Biologist, and Junior Forest Biologist, respectively, Unit of Forest Pathology, Laboratory of Forest Biology, Victoria, B.C. 
the application of pathological data to samples of a size sufficient to include a normal range in decay variation. Although sampling requirements of this nature are generally satisfied in extensive forest inventories, it is frequently desirable to designate smaller areas containing more or less than average defect to permit the utilization of marginal stands otherwise considered unmerchantable and provide data essential to the orderly removal of stands in priority of decadence. This report suggests the possibility of application of a tree decadence classification to mature coniferous stands to meet these requirements.

\section{Previous Studies}

Various attempts have been made to provide cull factors of direct application to individual trees and stands. It has been shown, for example, that decay may be correlated with the number and position of visible sporophores. In Sitka spruce on the Queen Charlotte Islands white pitted rot caused by Fomes pini (Thore) Lloyd, seldom extends to the basal log if sporophores are confined to the mid or upper bole (1). Single sporophores of the quinine fungus (Fomes laricis (Jacq.) Murr.) on the other hand may indicate an advanced development of decay throughout the greater portion of the merchantable length. Unfortunately, however, relatively few forest fungi produce sporophores on living trees, most fruiting being confined to slash and other dead material. In a number of cases, moreover, the small size and location of fruit bodies on the upper bole makes their presence of limited practical value as indicators of hidden defect in standing timber. Basal wounds and fire scars also may provide valuable information relative to hidden defect (3). In western coniferous species, however, roots may be of equal, if not greater, importance as avenues of entrance for fungi attacking the lower bole. Under such circumstances consideration of all visible malformations and injuries would seem necessary. Boyce (2) was one of the first investigators to make use of information of this nature. Following investigations of Douglas fir in Washington and Oregon, he concluded that scars, branch fans, dead limbs, burls, and frost cracks failed to provide reliable indications of hidden defect. Only $28 \%$ of the recorded scars, for example, were found to be infected. Sporophores and swollen knots associated with white pitted rot on the other hand provided reliable indices to approximately $80 \%$ of the total decay. Hornibrook (4) has outlined a method of estimating defect in spruce, pine and fire in the Central Rocky Mountain region. Standard scaling deductions as well as ocular estimates were applied to all visible abnormalities, and suggested methods of analysis included increment boring on two sides of the tree and sounding with an axe after partial removal of the bark. Although reliable estimates of net volume were obtained, detailed examinations of this nature are seldom feasible and the method would appear to be of more direct application to inventories of speciality products. Field procedures that appear to be of more practical value in extensive surveys have been presented by Kimmey 
(5) and Zillgitt (6). Kimmey has related the percentage of cull associated with sporophores, scars, and broken or dead tops to diameter and site index classes of Douglas fir and true fir in northern California. Zillgitt has established four tree classes for hardwood species in northern Minnesota based on the presence or absence and abundance of major and minor defect indicators. Major defect included, in part, conks, cankers, and broken or dead tops. Large seams, scars, and burls were also included in this category, but smaller defects of this nature were classed as indicators of minor importance. Average cull factors were provided for each of the preceding classes.

\section{Current InVESTigations}

Studies designed to establish a tree decadence classification for British Columbia species were begun in 1949 and the following classification proposed:

Suspect trees: living trees containing one or more abnormalities of decay significance,

Residual trees: living trees free from any abnormality of decay significance,

Dead trees: as shown by lack of green foliage.

It was suggested that trees be tallied in the foregoing classes and that representative trees be examined to determine average cull factors applicable to each class.

Subsequent investigations showed that sporophores, frost cracks, swollen knots, scars, dead tops, rotten branches, forked trees, and trunk infections of mistletoe could be classed as abnormalities significant of decay. (Plate I) Because sporophores and swollen knots are produced following the more or less extensive development of decay, their association with hidden defect may be regarded as reliable. It is not suggested that in every instance substantial volumes of decay will be associated with the remaining abnormalities. Negligible volumes of rot are to be expected, for example, in scars and dead tops of recent origin. Early desiccation of exposed heartwood and excessive pitch flow may also serve to retard or inhibit fungus infection. Despite the foregoing qualifications, present evidence demonstrates that the abnormalities listed may provide reliable, if not consistent, indications of hidden defect (Table I). Although these present data apply only to western hemlock in the Upper Columbia region, subsequent studies to date have not indicated any need for major revision in other areas. It is possible that the list could be extended to include additional abnormalities of local importance. Thus, exposed roots, dead branches, crook, or burls which were of minor, if any, significance in the Upper Columbia region may be shown to provide valid indications of hidden defect in other areas. For practical purposes in extensive inventories, however, it may be desirable to retain a uniform list as indicated herein or as modified to suit particular needs. 
Preliminary analyses of volumetric data segregated on the basis of the tree decadence index outlined above showed promising results. It was recognized, however, that further information was required to verify the reliability of the classification under various conditions of forest association. Accordingly, further studies were undertaken in western hemlock and amabilis fir in the Kitimat region, hemlock in the Upper Columbia region, and

TABLE I.

The Frequency of OcCurRence and Relative Importance of AbNormalities of Decay Significance on LIVING Western Hemlock IN THE UPPer COLUmbia Region.

(Basis 786 Trees)

\begin{tabular}{l|c|c|c}
\hline \multirow{2}{*}{ Abnormality } & $\begin{array}{c}\text { Frequency of } \\
\text { occurrence- } \\
\text { percentage of } \\
\text { living trees } \\
\text { affected. }\end{array}$ & \multicolumn{2}{|c}{$\begin{array}{c}\text { Percentage of affected trees } \\
\text { with decay }\end{array}$} \\
\cline { 4 - 4 } & 47.9 & $\begin{array}{c}\text { In direct associa- } \\
\text { tion with abnormal- } \\
\text { ities. }\end{array}$ & $\begin{array}{c}\text { In direct or } \\
\text { close-associa- } \\
\text { tion with } \\
\text { abnormalities. }\end{array}$ \\
\hline Sporophores & 100 & 100 \\
Frost cracks & 30.4 & 62 & 78 \\
Scars & 11.6 & 60 & 65 \\
Dead tops & 8.5 & 80 & 80 \\
Rotten branches & 7.1 & 90 & 90 \\
Forked trees & 3.6 & 60 & 71 \\
Swollen knots & 2.2 & 100 & 100 \\
Trunk-mistletoe & .8 & 75 & 75 \\
\hline
\end{tabular}

Engelmann spruce and alpine fir in the Bolean Lake area (Kamloops Forest District). Preliminary analyses of certain of the data are presented in Table II. The following comments are offered:

1. The classification does not attempt to designate sound trees. Although many of the Residual trees can be expected to be free from decay, the present data show that $28 \%$ to $62 \%$ contain measurable volumes of rot. It is to be noted, moreover, that $54 \%$ of the Suspect trees in one area were free from decay. Sound trees are not confined, therefore, to any of the classes currently designated.

2. The classification does not attempt to designate "cull" trees. AIthough most of the trees with greater than $50 \%$ rot were encountered in the Suspect class, at least one-third of them contained only moderate amounts of decay. Trees containing $80 \%$ or greater defect were encountered in each class. 
3. Minimum cull losses of $50 \%$ are to be anticipated in dead trees. It is not suggested that dead trees be tallied to estimate their net volume content, although this procedure might be entirely practical in certain areas where pulpwood utilization is under consideration. It is suggested, however, that an appreciation of the volumes contained in such trees would better serve to indicate the total productive capacity of a given site, as well as the extra time and effort required to remove or otherwise dispose of such material.

4. The classification provides for the segregation of trees into classes of high and low susceptibility to disease. In western hemlock in the Upper Columbia region $62 \%, 96 \%$, and $100 \%$ of the Residual, Suspect, and Dead trees, respectively, contained measurable amounts of decay. In the same species in the Kitimat region corresponding values were $46 \%, 65 \%$, and $100 \%$.

5. The classification is of value in designating tree classes having more or less than average defect. In western hemlock in the Upper Columbia region average cull losses of $12 \%, 55 \%$, and $95 \%$ were associated with the Residual, Suspect, and Dead trees respectively, In the Kitimat region corresponding values were $5 \%, 38 \%$, and $85 \%$.

6. The data derived for one tree species are not applicable to a different species in the same region. In the Kitimat region an average of $5 \%$ defect was associated with Residual western hemlock as compared to $13 \%$ in amabilis fir. At Bolean Lake cull factors of $6 \%$ and $11 \%$ were obtained for Residual spruce and balsam respectively.

7. These data appear to confirm the reliability of the classification in the species and regions under consideration. Although further experience may indicate the need for modification to meet various conditions of forest growth and stand disturbance, it would seem possible to apply the classification in its present form to mature coniferous stands throughout British Columbia. Revisions, if necessary, would become apparent following the subsequent examination of representative trees and the estimation of cull factors applicable to the specific region under consideration.

Some question may arise as to the increased accuracy, if any, over existing methods of forest inventory. In this connection reference may be made to certain values derived for western hemlock in the Upper Columbia region. Although an average defect value of $51 \%$ is to be anticipated in this region, studies have shown that inter-regional cull factors may vary from $38 \%$ to $74 \%$ in terms of cubic foot computations. Inventory estimates based on the application of a regional cull factor in stands of this nature may result in under- or over-estimates of net volume of $47 \%$ and $88 \%$ respectively. Inventory estimates based on the method proposed herein would reduce these errors by $8 \%$ and $16 \%$ respectively. Since the classification is intended to supplement, but not replace, correlations of decay with site, age, and diameter, further reductions in error are to be anticipated through multiple correlation 
with these latter variables. Studies of this latter nature will be presented in subsequent articles dealing with decay problems of regional importance in British Columbia.

\section{Literature Cited}

1. BIER, J. E. and FOSTER, R. E. The significance of conk rot in Sitka spruce on the Queen Charlotte Islands. B.C. Lumberman 30 , No. 5, 1946.

2. BOYCE, J. S. A study of decay in Douglas fir in the Pacific Northwest. U.S. Dept. Agr. Bull. 1163. 1923.

3. GARREN, K. M. Fire wounds on loblolly pine and their rclation to decay and other cull. Jour. For. 39 : 16-22, 1941 .

4. HORNIBROOK, E. M. Estimating defect in mature and overmature stands of three Rocky Mountain conifers. Jour, For. 48: 409-417. 1950.

5. KIMMEY, J. W. Cull factors for forest-tree species in Northwestern California. U.S. Dept. Agr. Forest Survey Release No. 7. 1950.

6. ZILLGITT, W. M. A quick method of estimating cull in northern hardwood stands. U.S. Dept. Agr. Tech. Note. 255. 1946. 